\title{
The stamina of Lebanese banks: A curious glitch in the midst of the liquidity crisis
}

\author{
Naimy, Viviane Y. \\ Karayan, Karen \\ - ReCEIVED: I March 2015 \\ - ACCEPTED: 27 MaRCH 2015
}

\begin{abstract}
This paper is the first to apply the econometric Chow model to determine the impact of the 2007-2008 financial crisis on the Lebanese banking sector through testing for structural breaks in their performance from the period immediately preceding the crisis until after the crisis hit. This involved the use of thirteen financial ratios for all the Lebanese commercial banks operating in Lebanon taken from the following four categories: profitability, liquidity, credit quality and capitalization. For comparison purposes, the chosen model was also applied to the 386 leading U.S. banks in terms of assets. A positive structural break was detected in the overall performance of Lebanese banks for profitability, liquidity and credit quality ratios. Conversely, U.S. banks showed a negative structural break in almost all of the selected ratio categories. Even though Lebanese banks showed a certain resilience, not to say improvement, in response to the crisis, they continue to be at risk due to their vulnerability to a number of macro, socio and political factors.
\end{abstract}

\section{Keywords:}

Chow test, Lebanese Banks, U.S. Banks, Structural breaks, Financial crisis.

\section{JEL classification:}

C12, C22; C32.

Naimy, V.Y. PhD. Professor of Finance, Faculty of Business Administration and Economics, Notre Dame University, Louaize, Lebanon. C) +9619218950 Ext:2274 Fax:+9619224517 D:+9619208336. Email:vnaimy@gmail.com.

Karayan, K. MBA,Anti Money Laundering and Compliance Officer, Online Money Transfer s.a.l, Sami El Solh, Lebanon. 


\title{
La resistencia de los bancos libaneses: una curiosa anomalía en la crisis de liquidez
}

\author{
Naimy, Viviane Y. \\ Karayan, Karen
}

\section{Resumen}

Este artículo es el primero que aplica el modelo econométrico de Chow para evaluar el impacto de la crisis financiera de 2007-2008 en el sector bancario libanés. Dicha aplicación se lleva a cabo mediante el contraste de cambios estructurales en su funcionamiento antes y después de la crisis. Para ello se utilizan trece ratios financieros relativos a la rentabilidad, liquidez, calidad del crédito y capitalización de los bancos comercialies libaneses que operan en el país. A efectos comparativos, el modelo anteriormente citado también se aplica a los 386 bancos estadounidenses más grandes en términos de activos. Se detecta un cambio estructural positivo en el rendimiento general de los bancos libaneses en lo que se refiere a rentabilidad, liquidez y calidad del crédito, mientras que los bancos de Estados Unidos muestran un comportamiento opuesto, es decir, un cambio estructural negativo en la mayoría de las ratios estudiadas. Si los bancos libaneses mostraron cierta resiliencia, por no decir mejora, a la crisis, ello no elimina el riesgo derivado de su vulnerabilidad a una serie de factores macro, sociales y políticos.

\section{Palabras clave:}

Test de Chow, bancos libaneses, bancos de Estados Unidos, cambios estructurales, crisis financiera. 


\section{Introduction}

The Great Depression of the 1930s in the U.S. was triggered by a financial crisis. Since then, several other world economies have seen their financial systems destroyed in a similar manner including Argentina in 2001 and Greece in 2009-2010. Similarly, the crisis which began in the U.S. in 2007 resulted in the worst global recession since the 1930s. The crisis spread rapidly from the U.S. to other countries and from financial markets to the real economy. It began in real estate with the collapse of the U.S. housing bubble and in the aftermath, all sectors of society had to incur huge losses, a great deal of wealth was wiped out, hundreds of institutions suffered and millions of jobs were lost. The crisis destroyed faith in the financial system, in free enterprise, and in economic theories too (De Bondt, 2010). The housing bubble had been preceded by a stock market bubble of comparable scale, resulting in a massive growth in global liquidity (Blyth, 2008). People saw a considerable increase in their capital with the unexpected rise of stock prices and increased their spending accordingly. The spending boom led consumers to buy better and larger homes as they wanted to spend some of their newly acquired wealth on real estate. This increase in demand triggered a housing bubble because the short-term supply of houses was, to a certain extent, fixed. Consequently, this rise in demand led to an increase in prices. While prices began to increase in the most affected areas, these increases came to be expected (Baker, 2008). The illusion of an indefinite increase of wealth resulting from the housing bubble triggered the most severe financial crisis in 75 years. The growth in global liquidity resulted in a sharp and sudden fall of long- and short-term interest rates; from that point on, both U.S. and global rates began their historic fall from double figures.

Regardless of where and when they occur, financial crises are complex events that have dire consequences for different parts of the financial system and the economy.

Faced with numerous episodes of financial and economic pressures in the past, in addition to having one of the highest government debt-to-GDP ratios in the world, the Lebanese economy should have undergone a crisis a long time ago (Gardner and Schimmelpfennig, 2008). However, it did not. The case of Lebanon, with its noncompliance with common theoretical financial crisis and debt sustainability models continues to be a mystery for many researchers and a source of confusion for economists.

Consequently, this paper examines this unique economy by studying its response to the financial crisis of 2007-2008, and more specifically how the performance of its banking sector was affected in order to determine the factors that helped to alleviate the severity of the crisis. For benchmarking purposes, the paper also examines the impact of the crisis on the U.S. banking sector through a quantitative method, using econometric models. 
The paper is structured as follows. Section 2 is a literature review of the impact of the crisis on certain countries' economies and banking sectors including those of Lebanon. Section 3 presents a review of the applied econometric model which aims to test for structural breaks and trend changes from the pre-crisis period to the postcrisis period using different financial ratios categories. For comparison purposes, the analysis will be conducted on a sample of Lebanese and U.S. banks. Section 4 provides the main findings of the research on both Lebanese and American banks. The final section contains the empirical findings and the concluding remarks.

\section{Literature review}

Studying the impact of the crisis on the Lebanese economy has appealed to a number of researchers. An interesting IMF research by Gardner and Schimmelpfennig (2008), for example, discusses how Lebanon was able to overcome the financial crisis. In their paper "Lebanon-Weathering the Perfect Storms", the authors review Lebanon's ability to manage financial pressures following severe shocks despite its large public debt and significant external vulnerabilities. The study was primarily based on qualitative data obtained through interviews and surveys conducted with market participants in Beirut and London for comparison purposes. It concludes that Lebanon was able to overcome the global liquidity crisis due to several characteristics of its market structure. Although this paper provides an interesting overview of the main vulnerabilities and advantages of the Lebanese economy during the crisis, it remains descriptive and lacks the quantification methods needed to measure the impact of the crisis on the Lebanese economy.

Nevertheless, quantitative measurements of the effect of the crisis on countries' economies and banking sectors has been well researched and has been the focus of much attention over the past seven years. Dietrich and Wanzenried (2010) show how Switzerland's banking sector was negatively affected by the global liquidity crisis by analyzing the profitability of 453 commercial banks in Switzerland over the period 1999-2008. The paper studies the impact of the crisis on bank profitability determinants as defined by the authors, such as bank-specific characteristics as well as industry-specific and macroeconomic factors. These determinants are investigated using a linear regression model. The major drawback of this research remains in the subjectivity of the bank profitability determinants chosen by the authors.

Akram et al. (2012) investigate the impact of the crisis on the financial performance of Pakistani banks. They analyze the various determinants of the banks' financial performance through the use of a multiple regression model. This is achieved by studying the relationship between the ROA and several bank-profitability determinants (deposits, 
investments, solvency, etc.) defined by the authors themselves. The comparison and analysis of these variables reveals that the global financial crisis exerted a significant impact on Pakistani banks. Although this study seems to give relevant and significant results, it provides no clear explanation of how the ROA ratio alone can determine the entire financial performance of banks, whereas in fact, a combination of a large number of ratios such as liquidity, profitability, and credit quality is typically used.

In their study, Olaniyi and Olabisi (2011) examine the causes and impacts of the global financial crisis on the performance of Nigerian banks. The authors apply the ordinary least square method of multiple regression analysis to manipulate the timeseries data into an econometric model of inflation; they also use the F-test to prove their hypotheses. The values of loans and advances, customers deposit and investment in securities are used as independent variables, while the dependent variable is the banks' performance ratio. The study concludes that the global financial crisis had a negative impact on the Nigerian banking sector.

Chan-Lau (2010) investigates how the global turmoil affected the risk of banks operating in Chile. The analysis is based on the study of default risk co-dependence, or CoRisk, between Chilean banks and global financial institutions using Expected Default Frequency measures to estimate default risk. The chosen model is applied to a sample of 51 financial institutions in 13 different American and European economies. The author concludes that the impact of the global liquidity crisis was limited, primarily resulting, at most, in a one-rating downgrade to Chilean banks.

Kumbirai and Webb (2010) study the performance of South Africa's commercial banking sector for the period 2005-2009. The paper employs a descriptive financial ratio analysis of profitability, liquidity and credit quality to measure, describe, analyze and assess the performance of five large South African-based commercial banks during that period. The study uses the t-test to examine whether the performance of the selected banks in 2005-2006 (prior to the crisis) is statistically different from that of 2008-2009 (during and after the crisis). The results show that overall bank performance increased considerably in the first two years of the analysis, however, a significant change in trends at the onset of the global financial crisis was observed, reaching its peak during 2008-2009. This was reflected in falling profitability, low liquidity and deteriorating credit quality in the South African Banking sector at the time.

Another similar study by Mehta (2012) examines the impact of the crisis on the financial performance of the banking sector in the UAE and uses profitability, liquidity and financial leverage ratios and analyzes them in order to compare the pre-crisis and post-crisis periods. Mehta (2012) applies the Wilcoxon Rank-Sum test, aiming to identify any change in trend from one period to another. The results suggest that the 
recent global financial crisis had some bearing on the performance of UAE banks, particularly in terms of profitability and liquidity.

\section{The model}

The chosen model to be applied to the Lebanese banking sector is the econometric "Chow Test" aiming to test for structural breaks and trend changes from the pre-crisis to the post-crisis period. In our study, the model employs a number of different financial ratios categories namely profitability, liquidity, credit quality and capitalization ratios.

The aim of this model is to illustrate whether the performance of the selected Lebanese and U.S. banks in the period prior to the crisis is statistically different from that of the period when the crisis struck and afterwards. This will enable us to determine whether there was a positive or negative change in the performance of those banks after the crisis hit; additionally, we will be able to determine if the Lebanese response to the crisis was similar to the response of American banks or if it diverged.

The model consists of using an F-test to verify whether the data tested is best determined using a single regression line or dividing the data into two sub-samples and performing two separate regressions. Clarification is provided in Figure 1:

\section{Figure 1. Chow test}

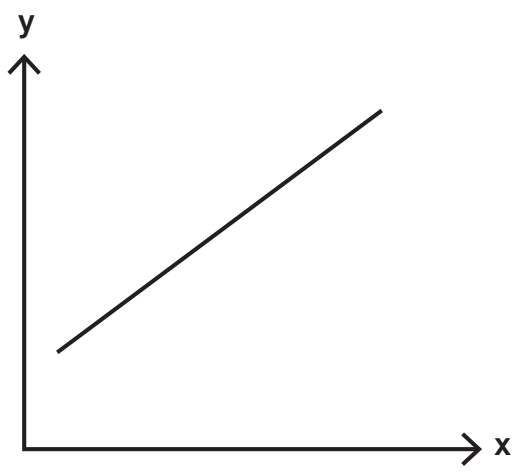

Case 1

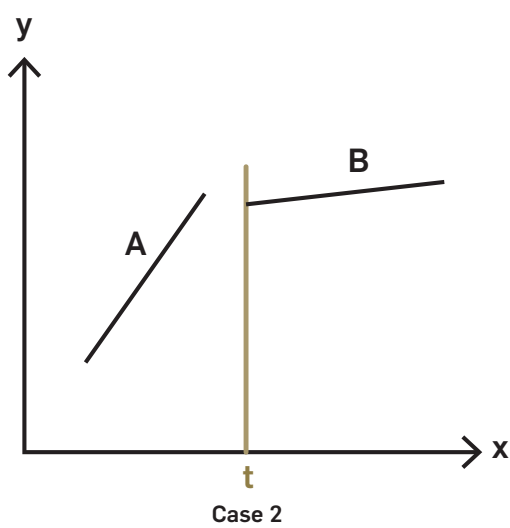

Case 2

This model enables us to determine if the Lebanese banks' tested ratios were continuous over time, presenting no structural break at the time of the crisis (similar to case 1); or if on the contrary, these ratios were affected by the global crisis and therefore reveal the occurrence of a structural break at the time the crisis hit or slightly afterwards (similar to case 2). The hypotheses to be tested using the Chow Test are as follows: 
$H_{0}$ : Parameters are stable; thus there is no significant difference between the precrisis and the post-crisis ratios of the selected sample banks.

$H_{1}$ : Parameters are not stable; thus there is a significant difference between the pre-crisis and the post-crisis ratios of the selected sample banks.

\subsection{Sample and data collection}

The choice of ratios to be tested for changes due to the crisis was based on the need for a broad sample of financial ratios representative of the general performance of a bank on different levels. For that purpose, the ratios chosen were divided into several categories in order to be able to tackle the effects of the crisis on all aspects of the banks and also to be able to determine, at later stages, which aspects of the banks were affected the most or the least by the crisis and why that should be.

As can be seen in Table 1, the ratios chosen were broken up into four main categories: Profitability Ratios which focus on the net income and enable us to measure how efficiently a bank is using its assets and managing its operations. Liquidity Ratios that provide information about the capacity of a bank to meet its obligations if funding is interrupted and about the risk of illiquidity. Credit Quality Ratios help in evaluating the risk of the bank's loans, particularly their ability to be collected prior to or upon maturity. And lastly, Capitalization Ratios to measure the solvency of the bank while analyzing its financial structure as well as its generation and use of capital through a combination of earning retention and debt (Hempel and Simonson, 1999).

\section{Table 1. Chosen ratios}

\begin{tabular}{|c|c|c|}
\hline \multicolumn{3}{|l|}{ Profitability Ratios } \\
\hline Ratio Name & Symbol & Equation \\
\hline Return on Average Assets & ROAA & ROAA $=$ Net Income $/$ Total Assets \\
\hline Return on Average Equity & ROAE & $\mathrm{ROAE}=$ Net Income $/$ Total Equity \\
\hline Cost to Income & C_I & $\begin{array}{l}\text { Cost to Income Ratio }=\text { Overheads } /(\text { Net Interest Revenue }+ \\
\text { Other Operating Income) }\end{array}$ \\
\hline Net Interest Margin & NIM & $\begin{array}{l}\text { Net Interest Margin }=\text { Net Interest Revenue } / \text { Average Earning } \\
\text { Assets }\end{array}$ \\
\hline Net Profit Margin & NI_REV & Net Profit Margin $=$ Net Income $/$ Net Interest Revenue \\
\hline \multicolumn{3}{|l|}{ Liquidity Ratios } \\
\hline Ratio Name & Symbol & Equation \\
\hline $\begin{array}{l}\text { Liquid Assets to Total } \\
\text { Deposits and Borrowing }\end{array}$ & LA_TDB & $\begin{array}{l}\text { Liquid Assets to Total Deposits and Borrowing = Liquid Assets } \\
\text { / Total Deposits and Borrowing }\end{array}$ \\
\hline Net Loans to Total Assets & $\mathrm{NL} \mathrm{TA}_{-}$ & Net Loans to Total Assets = Net Loans $/$Total Assets \\
\hline $\begin{array}{l}\text { Net Loans to Total Deposits and } \\
\text { Borrowing }\end{array}$ & NL_TDB & $\begin{array}{l}\text { Net Loans to Total Deposits and Borrowing }=\text { Net Loans } / \text { Total } \\
\text { Deposits and Borrowing }\end{array}$ \\
\hline
\end{tabular}


Credit Quality Ratios

\begin{tabular}{|c|c|c|}
\hline Ratio Name & Symbol & Equation \\
\hline $\begin{array}{l}\text { Loan Loss Reserves to Gross } \\
\text { Loans }\end{array}$ & LLR_GL & $\begin{array}{l}\text { Loan Loss Reserves to Gross Loans = Loan Loss Reserves / } \\
\text { (Net Loans + Loan Loss Reserves) }\end{array}$ \\
\hline Impaired Loans to Gross Loans & IL_GL & $\begin{array}{l}\text { Impaired Loans to Gross Loans = Impaired Loans / (Net Loans } \\
\text { + Loan Loss Reserves) }\end{array}$ \\
\hline Impaired Loans to Equity & IL_E & Impaired Loans to Equity = Impaired Loans / Total Equity \\
\hline
\end{tabular}

Capitalization Ratios

\begin{tabular}{lll}
\hline Ratio Name & Symbol & Equation \\
\hline Total Equity to Total Assets & E_TA & Total Equity to Total Assets = Total Equity / Total Assets \\
\hline Total Equity to Total Liabilities & E_L & $\begin{array}{l}\text { Total Equity to Total Liabilities = Total Equity / (Total Liabilities } \\
\text { and Equity - Total Equity - Hybrid Capital - Subordinated Debt) }\end{array}$ \\
\hline
\end{tabular}

The use of the above ratios extends from 2006 to 2012 in the case of the U.S banks, and from 2005 to 2011 for the Lebanese banks, with 2007 being set as the breakpoint, the year when the first signs of the crisis began to appear. The period chosen to evaluate Lebanese banks differs slightly from that for U.S. banks due to the limited availability of data. The ratios are sourced from Bankscope, a comprehensive global database of banks' intelligence, ratings and financial statements (Bankscope, 2012).

Because the data distribution is unknown, we chose Slovin's formula sampling technique.

$$
n=\frac{N}{\left(1+N \times e^{2}\right)}
$$

Where:

$n=$ Sample size

$N=$ Total population; which is in our case the total number of banks provided by Bankscope for the U.S. and Lebanon

$e=$ Error tolerance; we chose a $5 \%$ error margin.

This sampling technique was applied only to U.S. banks since the population provided by Bankscope was very large $\left(N_{u s}=10,307\right.$ banks $)$. Therefore:

$$
n_{u s}=\frac{N_{u s}}{\left(1+N_{u s} \times e^{2}\right)}=\frac{10,307}{\left(1+10,307 \times 0.05^{2}\right)}=386 \text { banks; }
$$

We chose the top 386 U.S. banks in terms of total assets since these banks represent the largest share of the U.S. banking sector's total assets and thus have the biggest impact on its overall performance.

In the case of Lebanon, Bankscope provided data for 40 banks, equating to $98 \%$ of operating commercial banks, consequently all 40 banks were included in the sample.

$$
n_{l e b}=N_{l e b}=40 \text { banks }
$$


The U.S. sample comprises $35,126^{1}$ observations compared to $3,640^{2}$ for the Lebanese one.

\subsection{Data manipulation}

All bank data for each ratio are averaged. The weighted-average method applied is based on the total assets of each bank since banks belonging to the same economy differ in size; consequently banks which represent the biggest share of the banking sector's total assets have the biggest impact on its overall performance, while banks with lower total assets have a lesser impact. The weighted average for each ratio is as follow:

$$
\text { Weighted Average of Ratio } A_{\text {year } x}=\frac{\sum_{i=1}^{n}\left(T A_{i} \times \text { Ratio } A_{i}\right)}{\sum_{i=1}^{n} T A_{i}}
$$

Where:

$n=$ number of banks presenting a value for Ratio $A$

$T A_{i}=$ total assets of bank $i$

$\sum_{i=1}^{n} T A_{i}=$ sum of total assets of all banks presenting a value for Ratio $A$

The yearly weighted averages for each ratio for U.S. and Lebanese banks are presented in Tables 2 and 3.

Table 2. Weighted ratios for the selected U.S. banks

\begin{tabular}{lrrrrrrrrrrrrrrr} 
& \multicolumn{4}{c}{$\begin{array}{c}\text { PROFITABILITY } \\
\text { RATIOS }\end{array}$} & \multicolumn{4}{c}{$\begin{array}{c}\text { LIQUIDITY } \\
\text { RATIOS }\end{array}$} & \multicolumn{2}{c}{$\begin{array}{c}\text { CREIT QUALITY } \\
\text { RATIOS }\end{array}$} & \multicolumn{3}{c}{$\begin{array}{c}\text { CAPITALIZATION } \\
\text { RATIOS }\end{array}$} \\
\hline YEAR & ROAA & ROAE & C_I & NIM & NI_REV & LA_TDB & NL_TA & NL_TDB & LLR_GL & IL_GL & IL_E & E_TA & E_L \\
\hline 2005 & 1.27 & 14.95 & 57.73 & 2.29 & -49.74 & 28.10 & 44.80 & 58.51 & 0.99 & 1.42 & 6.16 & 8.12 & 10.24 \\
\hline 2006 & 0.72 & 5.20 & 82.06 & 2.22 & -39.79 & 28.17 & 44.67 & 55.18 & 1.21 & 2.10 & 10.24 & 7.83 & 9.56 \\
\hline 2007 & -0.85 & -42.09 & 57.09 & 2.43 & -1.02 & 30.13 & 43.85 & 53.34 & 2.12 & 2.28 & 7.79 & 6.55 & 8.31 \\
\hline 2008 & -0.46 & 53.82 & 55.38 & 2.61 & -0.40 & 30.47 & 40.46 & 48.62 & 3.27 & 5.22 & 35.36 & 7.98 & 9.84 \\
\hline 2009 & 0.52 & -16.23 & 57.48 & 2.67 & 0.04 & 32.52 & 47.78 & 55.83 & 3.27 & 4.43 & 14.24 & 8.29 & 9.94 \\
\hline 2010 & 0.61 & 47.83 & 61.26 & 2.49 & 0.57 & 32.48 & 49.17 & 57.53 & 2.53 & 4.11 & 13.28 & 8.38 & 9.95 \\
\hline 2011 & 0.79 & 20.86 & 58.66 & 2.42 & 0.25 & 28.54 & 50.08 & 59.25 & 2.08 & 3.81 & 11.14 & 8.88 & 10.32 \\
\hline
\end{tabular}

Table 3. Weighted ratios for the selected Lebanese banks

\begin{tabular}{|c|c|c|c|c|c|c|c|c|c|c|c|c|c|}
\hline \multirow[b]{2}{*}{ YEAR } & \multicolumn{5}{|c|}{$\begin{array}{l}\text { PROFITABILITY } \\
\text { RATIOS }\end{array}$} & \multicolumn{3}{|c|}{$\begin{array}{l}\text { LIQUIDITY } \\
\text { RATIOS }\end{array}$} & \multicolumn{3}{|c|}{$\begin{array}{l}\text { CREDIT QUALITY } \\
\text { RATIOS }\end{array}$} & \multicolumn{2}{|c|}{$\begin{array}{l}\text { CAPITALIZATION } \\
\text { RATIOS }\end{array}$} \\
\hline & ROAA & ROAE & C_I & NIM & NI_REV & LA_TDB & NL_TA & NL_TDB & LLR_GL & IL_GL & IL_E & E_TA & E_L \\
\hline 2005 & 0.77 & 11.75 & 59.99 & 2.81 & 0.38 & 44.31 & 20.81 & 23.47 & 8.49 & 11.55 & 63.59 & 7.98 & 8.76 \\
\hline 2006 & 0.84 & 10.44 & 58.42 & 2.90 & 0.36 & 43.87 & 23.57 & 24.10 & 8.52 & 10.85 & 32.87 & 8.83 & 9.78 \\
\hline 2007 & 0.94 & 10.75 & 58.85 & 2.68 & 0.45 & 42.23 & 23.51 & 26.45 & 8.73 & 12.63 & 46.95 & 8.58 & 9.61 \\
\hline 2008 & 1.09 & 13.02 & 55.22 & 2.81 & 0.49 & 34.11 & 26.67 & 30.49 & 7.03 & 9.18 & 30.55 & 8.81 & 9.76 \\
\hline 2009 & 1.14 & 13.21 & 52.05 & 2.45 & 0.59 & 34.63 & 25.50 & 28.47 & 6.02 & 9.41 & 30.14 & 8.97 & 9.97 \\
\hline 2010 & 1.27 & 14.46 & 48.11 & 2.41 & 0.62 & 29.11 & 31.60 & 35.48 & 5.09 & 7.17 & 23.60 & 9.19 & 10.22 \\
\hline 2011 & 1.13 & 13.09 & 49.10 & 2.35 & 0.60 & 33.12 & 28.72 & 32.12 & 4.35 & 5.32 & 23.48 & 8.41 & 9.25 \\
\hline
\end{tabular}

\footnotetext{
17 years covering 13 different ratios for 386 U.S. banks.

27 years covering 13 different ratios for 40 Lebanese banks.
} 


\section{Findings}

Estimating the regression of each ratio from 2006 to 2012 for U.S. banks, and from 2005 to 2011 for Lebanese banks was carried out after splitting the data into two subperiods at the designated breakpoint year, 2007. The regression for the two sub-periods was then estimated separately. We obtained the residual sum of squares (RSS) for each of the three regressions and performed the $F$-test for each ratio within the two samples.

$$
F=\frac{R S S-\left(R S S_{1}+R S S_{2}\right)}{R S S_{1}+R S S_{2}} \times \frac{T-2 k}{k}
$$

Where:

$R S S=$ residual sum of squares for the whole sample

$R S S_{1}=$ residual sum of squares of sub-sample 1

$R S_{2}=$ residual sum of squares of sub-sample 2

$T$ = number of observations

$k=$ number of regressors in each regression

We found the P-value 3 interval for the calculated F-value and finally the P-value. The chosen confidence level is $90 \%$. Tables 4 and 5 show the results of the Chow test per ratio for the U.S. and Lebanon respectively.

Table 4. Chow test results for the selected U.S. banks

\begin{tabular}{llrrr}
\hline \multirow{2}{*}{ RATIO NAME } & \multirow{2}{*}{ ACRONYM } & \multicolumn{3}{c}{ U.S. } \\
\cline { 3 - 5 } & & F-VALUE & P-VALUE & DECISION \\
\hline Return on Average Assets & ROAA & 2.39239 & 0.1826 & Accept $\mathrm{H}_{0}$ \\
\hline Return on Average Equity & ROAE & 0.00792 & 0.9325 & Accept $\mathrm{H}_{0}$ \\
\hline Cost to Income & C_I & 3.22482 & 0.1325 & Accept $\mathrm{H}_{0}$ \\
\hline Net Interest Margin & NIM & 9.87251 & 0.0256 & Reject $\mathrm{H}_{0}$ \\
\hline Net Profit Margin & NI_Rev & 278.83490 & 0.0000 & Reject $\mathrm{H}_{0}$ \\
\hline Liquid Assets to Total Deposits and Borrowing & LA_TDB & 4.54194 & 0.0863 & Reject $\mathrm{H}_{0}$ \\
\hline Net Loans to Total Assets & NL_TA & 0.25903 & 0.6324 & Accept $\mathrm{H}_{0}$ \\
\hline Net Loans to Total Deposits and Borrowing & NL_TDB & 0.35925 & 0.5750 & Accept $\mathrm{H}_{0}$ \\
\hline Loan Loss Reserves to Gross Loans & LLR_GL & 12.24240 & 0.0173 & Reject $\mathrm{H}_{0}$ \\
\hline Impaired Loans to Gross Loans & IL_GL & 7.10680 & 0.0446 & Reject $\mathrm{H}_{0}$ \\
\hline Impaired Loans to Equity & IL_E & 0.98337 & 0.3669 & Accept $\mathrm{H}_{0}$ \\
\hline Total Equity to Total Assets & E_TA & 0.00331 & 0.9564 & Accept $\mathrm{H}_{0}$ \\
\hline Total Equity to Total Liabilities & E_L & 0.13669 & 0.7267 & Accept $\mathrm{H}_{0}$ \\
\hline
\end{tabular}

\footnotetext{
${ }^{3}$ Where: Degrees of fredom of numerator $=d f n=k$. Degrees of fredom of denominator $=d f d=T-2 k$
} 
Table 5. Chow test results for the selected Lebanese banks

\begin{tabular}{llrrr}
\hline \multirow{2}{*}{ RATIO NAME } & ACRONYM & \multicolumn{3}{c}{ LEBANON } \\
\cline { 2 - 5 } Return on Average Assets & ROAA & 25.5878 & 0.0039 & Reject $\mathrm{H}_{0}$ \\
\hline Return on Average Equity & ROAE & 22.3506 & 0.0052 & Reject $\mathrm{H}_{0}$ \\
\hline Cost to Income & C_I & 16.9238 & 0.0092 & Reject $\mathrm{H}_{0}$ \\
\hline Net Interest Margin & NIM & 4.88853 & 0.078 & Reject $\mathrm{H}_{0}$ \\
\hline Net Profit Margin & NI_Rev & 17.1243 & 0.009 & Reject $\mathrm{H}_{0}$ \\
\hline Liquid Assets to Total Deposits and Borrowing & LA_TDB & 46.682 & 0.001 & Reject $\mathrm{H}_{0}$ \\
\hline Net Loans to Total Assets & NL_TA & 9.80703 & 0.0259 & Reject $\mathrm{H}_{0}$ \\
\hline Net Loans to Total Deposits and Borrowing & NL_TDB & 13.2645 & 0.0149 & Reject $\mathrm{H}_{0}$ \\
\hline Loan Loss Reserves to Gross Loans & LLR_GL & 18.398 & 0.0078 & Reject $\mathrm{H}_{0}$ \\
\hline Impaired Loans to Gross Loans & IL_GL & 10.3441 & 0.0236 & Reject $\mathrm{H}_{0}$ \\
\hline Impaired Loans to Equity & IL_E & 7.18349 & 0.0438 & Reject $\mathrm{H}_{0}$ \\
\hline Total Equity to Total Assets & E_TA & 1.76957 & 0.2409 & Accept $\mathrm{H}_{0}$ \\
\hline Total Equity to Total Liabilities & E_L & 1.35557 & 0.2968 & Accept $\mathrm{H}_{0}$ \\
\hline
\end{tabular}

Table 5 shows that the global liquidity crisis did have an impact on Lebanese banks given that most of the ratios' performances reveal changes in trend before and after the crisis, thus showing breaks. The positive nature of those breaks is discussed below. Similarly, and as can be seen in Table 4, all credit quality ratios and some of the profitability and liquidity ratios presented breakpoints at the time of the crisis for the U.S. banks. Only capitalization ratios showed some degree of resilience.

\section{Profitability ratios}

This ratio category for Lebanese banks experienced important breaks. All ratios in this category showed significant change in trend throughout the selected period but surprisingly, the change in trends was positive reflecting greater profitability, stronger management of net interest margin and improved net income to net interest revenue. Unlike certain U.S. profitability ratios, primarily the Net Interest Margin, NIM, and the Net Profit Margin, NI_REV, which witnessed severe negative structural breaks. In 2007, NI_REV reached $-39.79 \%$ and remained unstable afterward. The Cost to Income ratio did not show any break, as can be seen in Table 4, however, structural disequilibrium did take place between 2006 and 2007 where it reached its highest value over the seven-year period under study, 82\%, and maintained an average of 58\% from 2007 to 2012, an average explained by the severe layoffs together with a decrease in net interest revenue.

\section{Liquidity ratios}

Liquidity ratios of Lebanese banks also witnessed positive breaks. In fact, the Liquid Assets to Total Deposits and Borrowing ratio experienced a steeper downward 
movement between the years 2007 and 2008 due to the $13 \%$ increase in deposits (from LBP 90,629 billion in 2007 to LBP 102,632 billion in 2008). The evolution of the Net Loans to Total Assets ratio was the result of the increase in gross loans granted to both the private and the public sectors during that period. Chow test results for the U.S. liquidity ratios category show that the Liquid Assets to Total Deposits and Borrowing ratio experienced a break during the selected period. In contrast, the Net Loans to Total Assets and the Net Loans to Total Deposits and Borrowing ratios presented some stability throughout.

\section{Credit quality ratios}

Lebanese banks' credit quality ratios experienced a positive break. The ratios in this category witnessed significant changes in trend. Thanks to the tightening of banking regulations by the country's monetary and supervisory authorities in order to avert any repercussions of the global financial crisis, the evolution of the Impaired Loans to Gross Loans ratio witnessed a decrease during the selected period. Lebanese banks were required to maintain high levels of liquidity in both domestic and foreign currencies (exceeding an average of $35 \%$ of their total deposits). Loan Loss Reserves to Gross Loans ratio from 2007 to 2008 showed a similar trend. However, the growth of loans granted in the following years resulted with a parallel increase in loan loss reserves. The Impaired Loans to Equity ratio followed a decreasing trend as well, mainly due to the rise in commercial banks' equity resulting from the continuous increase in their profits during that period: net profits after tax increased by $26 \%$ between 2007 and 2008, followed by a 12\% rise the following year. This increase in profits was triggered by the growth of income received from interest paid by customers, net commissions received and from other sources of revenue (such as returns on financial instruments), which experienced a faster increase than that of interest revenues, particularly after the global crisis hit. It shows that Lebanese banks started relying on other sources of income during that period. Additionally, the significant decrease in net provisions and other operating expenses from 2007 to 2008 contributed to further increasing profits during that year.

The considerable rise of impaired loans in the U.S. banking sector greatly affected the Impaired Loans to Gross Loans ratio which presented a notable negative break in the year 2008. This increase resulted from the "easy credit" strategy adopted at the time. In fact, the attractive housing market led to the rise of mortgage lending of all types as well as the emergence of specialized, unregulated mortgage lenders and the creation of a variety of sub-prime loans. On the other hand, mortgage brokers and underwriters had every reason and incentive to sell these types of loans. Once the housing bubble burst, and prices started to fall, the refinancing of those loans became more and more difficult and homeowners started to progressively default, thus converting these loans into impaired, nonperforming ones (Bianco, 2008). 
Lastly, the Impaired Loans to Equity ratio did not experience a break during the selected period according to the results in Table 4; however, this ratio witnessed an increase in 2009, reaching $35.36 \%$ due to the rise in impaired loans as a result of the severe loan losses incurred by U.S. commercial banks immediately after the crisis hit.

\section{Capitalization ratios}

In the case of Lebanese banks, as shown in the Chow test results in Table 5, neither of the ratios in this category experienced any break, revealed by a change of trend after 2007. In fact, a positive evolution of those ratios was observed, whereby they increased continuously during the peak years of the crisis (from 2007 to 2010). This increasing trend was initially a result of the increase in bank profits over this period and later from the implementation of the Basel II and III capital requirements. In 2011, Lebanese banks were highly capitalized with their Capital Adequacy Ratio (CAR) reaching $12 \%{ }^{4}$. Starting in 2012, the Central Bank required a progressive increase of Common Equity Tier 1 ratio $^{5}$ to $8 \%$, Tier 1 ratio $^{6}$ to $10 \%$ and a total capital ratio $^{7}$ to $12 \%$ by the end of 2015 thus meeting the requirements of Basel III, which recommended that $7 \%, 8.5 \%$ and $10.5 \%$ ratios consecutively be applied at the beginning of 2019 .

For the U.S. banking sector, the Chow test results did not show any structural breaks in the evolution of either the Total Equity to Total Assets or the Total Equity to Total Liabilities ratios. However, the selected ratios slightly decreased in 2007 reaching their lowest value in 2008. This decrease is explained by the fall in equity as a result of the huge losses incurred by U.S. banks at that time; in a very short period, major U.S. banks had hit rock bottom and were either bankrupt, taken over or bailed out (Mankiw and Ball, 2010). In 2009, both ratios started to progressively increase following equity injections by the U.S. treasury. Instead of purchasing the assets of failing financial institutions, it purchased shares in the institutions themselves, thus increasing their equity by injecting additional capital to protect depositors and absorb unexpected losses (Mankiw and Ball, 2010). Another important factor that contributed to the increase in the equity of U.S. banks at that time, thus avoiding structural breaks, was the delayed implementation of Basel II capital requirements in January 2009, which required banks to maintain their level of capital equal to at least $8 \%$ of their risk-weighted assets. An additional factor which facilitated the increase in equity was the introduction of the Dodd-Frank Act in 2010, which contained a

\footnotetext{
${ }^{4}$ Knowing that the public debt id weighted zero.

${ }^{5}$ Common Equity Tier I ratio being the ratio of common equity Tier I capital to total weighted assets (Basel III Handbook, 20I2).

${ }^{6}$ Tier I ratio being the ratio of Tier I capital to total risk weighted assets (Basel III Handbook, 20I2).

${ }^{7}$ Total capital ratio or capital adequacy ratio being the ratio of the sum of the Tier I ratio and the Tier 2 ratio to total weighted assets (Basel III Handbook, 20I2).
} 
number of provisions to protect consumers and investors, avoid future bailouts, and monitor financial system operations more carefully. (Wall Street Reform: The DoddFrank Act).

\section{Discussion and conclusion}

It is no surprise to see U.S. banks' selected ratios experiencing a structural break and instability when the crisis occurred. But the absence of any signs of deterioration whatsoever, and the presence of positive breaks in almost all the ratio categories when applying the Chow test to the Lebanese banks' ratios, constituted a real revelation for many analysts. Merely the continued existence of vulnerability factors from 1990 to the present day is enough to threaten the soundness of the major economic sectors of the country and make it collapse. A major weakness of the Lebanese economy is certainly its large public debt together with its government's fiscal deficit. The government budget has been in continuous deficit over the years with an average of $35 \%$ of government expenditure allocated to the public debt service and repayment, and $33 \%$ to public wages and salaries. The Lebanese government has never been able to allocate funds to improve the country's poor infrastructure - roads, public schools, health sector, etc. Furthermore, the lack of public spending on productive projects for the most part limited the government's revenue sources to taxes only (70\%).

The net public debt has been negatively progressing, increasing by a yearly average of $5 \%$ during the selected period of our study (2005-2012). In fact it started to rise in 1994. This public debt intended to be a source of constructive financing for the country is practically draining the government resources, reaching $160 \%$ of the national GDP in 2014. Most dangerously, the banking sector constitutes the most indispensable source of public debt financing. The Lebanese banks are acting as the government's main creditor, funding on average up to $60 \%$ of the gross public debt since 1994. The ability of the banking sector to finance the government lies on the continuously growing deposit base of those banks. In other words, the continuous growth of public debt creates the accumulation of deposits. Deposits and public debt are following exactly the same increasing tempo with no end in sight (Naimy, 2011). This monumental rolled-over public debt became the substitute for and the source of wealth at the same time. It is the substitute for wealth and productivity because it finances consumption and deficit and constitutes the main substance of local wealth. This public debt is the best representative facet of an 'active socio-economic model' well managed and equipped to marginalize and eliminate the country's middle class -an active model that uses strategies based on corruption, concentration of fortunes and strong incentive to emigrate- a model that led to the severe failure of the Lebanese government in its mission (Naimy, 2003). 
The Lebanese commercial banks showed some resilience toward the financial crisis, primarily due to their traditionally conservative approach to speculation in subprime mortgages and in any other risky packages of structured products and bundled-up debt, to liquidity requirement with an average liquidity ratio of $40 \%$ (Naimy, 2011), and to the introduction of the bank merger law, that forces weak banks to merge with strong ones. However, and irrespective of the statistical results of this study, a single adverse shock can drive a sound banking sector into bankruptcy within a short period of time. The Lebanese economic system has a unique, complicated, and complex equation to decipher and understand. Indeed, the facts do not comply with any theoretical model and will always remain a source of confusion for outside observers and analysts.

\section{References}

Akram, M.I., Safdar, R. and Mian, N.S. (2012). Impact of Global Financial Crisis on Banks' Financial Performance in Pakistan, American Journal of Scientific Research, 78, pp. 101-110.

Auer, M. and Von Pfoestl, G. (2012). Basel III Handbook. Accenture. Available at: http://www.accenture.com/ SiteCollectionDocuments/PDF/Accenture-Basel-III-Handbook.pdf [Accessed 3 June 2013].

Baker, D. (2008). The Housing Bubble and the Financial Crisis, Real-World Economics Review, 46, pp. 73-81.

Bankscope (2012). Company Information and Business Intelligence. Available at: http://www.bvdinfo.com/ Products/Company-Information/International/BANKSCOPE.aspx. [Accessed 3 June 2013].

Bianco, K. (2008). The Subprime Lending Crisis: Causes and Effects of the Mortgage Meltdown, Wolters KluwerCCH Group. Available at: http://business.cch.com/images/banner/subprime.pdf [Accessed 5 June 2013].

Blyth, M. (2008). The politics of compounding bubbles: The global housing bubble in comparative perspective, Comparative European Politics, 6(3), pp. 387-406.

Chan-Lau, J. (2010). The Global Financial Crisis and its Impact on the Chilean Banking System. WP/10/108, International Monetary Fund, Washington, D.C.

De Bondt, W. (2010). The Crisis of 2008 and Financial Reform, Emerald, 2(3), pp. 137-156.

Dietrich, A. and Wanzenried, G. (2010). Determinants of Bank Profitability before and during the Crisis: Evidence from Switzerland, Journal of International Financial Markets, Institutions and Money, 21(3), pp. 307-327.

Gardner, E.H. and Schimmelpfennig, A. (2008). Lebanon-Weathering the Perfect Storms, WP/08/17, International Monetary Fund, Washington, D.C.

Hempel, G. and Simonson, D. (1999). Evaluating a Bank's Returns, Risks and Overall Performance. Bank Management: Text and Cases, John Wiley and Sons, Inc., New York. 
Kumbirai, M. and Webb, R. (2010). A Financial Ratio Analysis of Commercial Bank Performance in South Africa. African Review of Economics and Finance, 2(1), pp. 30-53.

Mankiw, G.N. and Ball, L.M. (2010). Financial Crises. Macroeconomics and the Financial System, Worth Publishers, pp. 537-572.

Mehta, A. (2012). Financial Performance of UAE Banking Sector- A Comparison of before and during Crisis Ratios. International Journal of Trade, Economics and Finance, 3(5), pp. 381-387.

Naimy V. (2011). Failure Prediction With Logit and Bank-Level Fundamentals Models Applied on the Lebanese Commercial Banks, The Journal of American Academy of Business, Cambridge, 16(3), pp. 189-196.

Naimy V. (2003). Emerging Markets, Financing of SME's and Economic Growth: The Case of Lebanon, Notre Dame University Press, Lebanon.

Olaniyi, A.T. and Olabisi, Y.O. (2011). Causes and Impacts of Global Financial Crisis on the Performance of Nigerian Banks (a case study of selected banks), Journal of Business Management and Economics, 2(4), pp. 164-170.

The White House (n.d.). Wall Street Reform: The Dodd-Frank Act. Available at: http://www.whitehouse.gov/ economy/middle-class/dodd-frank-wall-street-reform [Accessed: 10 March 2014].■ 